\title{
ПОДГОТОВКА ИНЖЕНЕРОВ ДЛЯ ТАНКОСТРОИТЕЛЬНОЙ ПРОМЫШЛЕННОСТИ БОЛГАРИИ В ХАРЬКОВСКОМ ПОЛИТЕХНИЧЕСКОМ ИНСТИТУТЕ (1972-1992 ГГ.)
}

\author{
Е. Е. Александров
}

Как известно, в странах Организации Варшавского Договора было организовано производство вооружений и военной техники, в основном по лицензиям СССР. Народная Республика Болгария, в частности, выпускала гусеничный многоцелевой бронированный транспортер-тягач МТ-ЛБ, разработанный и производимый на Харьковском тракторном заводе (ХТЗ). Для этого в городе Червен бряг был построен Машиностроительный комбинат «Девети май», оснащенный самым современным станочным парком и другим технологическим оборудованием, закупленным в странах Западной Европы. При МК «Девети май» открылся научно-исследовательский институт технологии транспортного машиностроения, занимавшийся, помимо разработки и усовершенствования технологических процессов создания систем и агрегатов транспортных машин, вопросами конструирования машин и научного сопровождения разработок новой транспортной техники. МК «Девети май» являлся по сути градообразующим предприятием, давшим мощный импульс развитию Червен брягу. В городе был создан машиностроительный техникум и профессионально-техническое училище, началось интенсивное жилищное строительство; были возведены также великолепный культурно-просветительский центр, огромный универмаг и современный продуктовый супермаркет; получил интенсивное развитие общественный транспорт. Подчинялся МК «Девети май» Государственному объединению «Металхим», которое практически являлось министерством машиностроительной и химической промышленности НРБ.

Еще одним центром танковой промышленности НРБ стал город Тырговиште в восточной части страны. Там был создан танкостроительный завод, где ремонтировались танки вооруженных сил НРБ. Предприятие подчинялось Министерству обороны НРБ, поэтому руководители предприятия были кадровыми военными и носили военную форму. На вооружении болгарской армии стояли советские танки - модернизированные Т-55 и современные Т-72. Производственная база предприятия также была суперсовременной.

Система высшего и среднего специального образования НРБ не предусматривала подготовку специалистов для оборонной промышленности страны. Специалистов для предприятий танкового профиля готовили в СССР - Академия танковых войск имени Маршала Советского Союза Р. Я. Малиновского для танкоремонтного завода в г. Тырговиште и Ленинградский политехнический институт для МК «Девети май». Однако после создания в 1972 г. кафедры колесных и гусеничных машин (КГМ) в Харьковском политехническом институте (ХПИ) подготовка специалистов танкостроителей для НРБ сосредоточилась только на кафедре КГМ, на которой мне довелось работать с момента учреждения. Эта подготовка осуществлялась ровно 20 лет - с 1972 года по 1992 год, прекратившись после самороспуска ОВД и распада СССР.

Договор между НРБ и СССР на подготовку инженеров-танкостроителей предусматривал ежегодный прием на первый курс 15 болгарских студентов, поэтому руководством ХПИ было решено создать отдельную академическую группу, состоящую целиком из болгар. В связи с тем, что все командированные из НРБ студенты прошли службу в вооруженных силах НРБ, было решено освободить их от прохождения курса военной подготовки в ХПИ. Освободившийся день недели, отведенный для военной подготовки, заполнялся дополнительными занятиями по профилирующим курсам специальности 15.06 - гусеничные и колесные машины. Учебный план подготовки болгарских студентов включал расширенные курсы «Конструирование и расчет гусеничных машин». Число часов, составляющих эти курсы, практически в два раза превышало объем соответствующих курсов для советских студентов. Такое решение весьма благотворно влияло на подготовку инженеров для НРБ.

Следует отметить, что болгарская сторона весьма ответственно подходила к отбору студентов для учебы в ХПИ. Это были, как правило, юноши, имеющие хорошую школьную подготовку и положительно характеризуемые командирами части и подразделений армии НРБ, где они проходили службу. Проживали болгарские студенты не в специальных общежитиях

(C) Александров, Е. Е., 2016 
для иностранцев, а вместе с советскими студентами. Прекрасное знание русского языка способствовало дружеским отношениям болгарских и советских студентов.

Учитывая великолепную техническую оснащенность предприятий МК «Девети май» и танкоремонтного завода в Тырговиште, по договоренности с болгарской стороной было принято решение о проведении производственных практик болгарских студентов на предприятиях НРБ. Ознакомительная практика после первого курса обучения проводилась на ХТЗ им. С. Орджоникидзе, технологическая практика после третьего курса - на МК «Девети май» в г. Червен бряг, ремонтно-эксплуатационная практика после четвертого курса - на танкостроительном заводе в г. Тырговиште, а преддипломная практика после пятого курса - на обоих болгарских предприятиях, в зависимости от места распределения студентов. Такая система позволяла студентам еще задолго до защиты дипломов ознакомиться с местом распределения и спецификой будущей деятельности.

Руководили производственными практиками в НРБ ведущие преподаватели кафедры КГМ: технологической - доценты Н. Н. Палащенко, О. И. Абляский, Н. Г. Медведев; ремонтноэксплуатационной - доценты В. К. Белов, В. Б. Самородов, В. Н. Омельченко; преддипломной профессор Е. Е. Александров, доценты В. П. Писарев и В. Н. Трушкин.

Лучшие выпускники кафедры КГМ-граждане НРБ еще во время учебы в ХПИ проявили желание стать специалистами высшей квалификации - кандидатами наук. Николай Калейчев и Огнян Марковски успешно прошли курс аспирантуры и под руководством профессора В. П. Аврамова защитили кандидатские диссертации. Тема диссертации Н. Калейчева была связана с повышением плавности хода быстроходных гусеничных машин, а тема О. Марковски - с разработкой системы охлаждения моторно-трансмиссионной установки гусеничных транспортеров-тягачей.

Руководство ГО «Металхим» и промышленных предприятий оборонной промышленности НРБ высоко оценивали подготовку инженеров и научных кадров для оборонной промышленности. Между ГО «Металхим» и ХПИ в 1985 году было заключено соглашение о ежегодном проведении на базе Научно-исследовательского технологического института (г. Червен бряг) международных научно-технических конференций в области транспортного машиностроения. Проведение таких конференций, в которых принимали участие заместитель министра обороны НРБ П. Спиридонов, генеральный директор МК «Девети май» П. Петров, главный конструктор Г. Априлов, заместители директора И. Колев и Т. Павлов, профессор Машиностроительного института И. Димитров (г. Русе, НРБ), заведующий кафедрой КГМ ХПИ профессор В. П. Аврамов, профессоры этой кафедры Е. Е. Александров, В. Б. Самородов, Н. Г. Медведев, В. Н. Омельченко и др., способствовали интеграции научных исследований, проводимых учеными НРБ и СССР в области транспортного машиностроения.

За подготовку высококвалифицированных специалистов для НРБ к 100-летию ХПИ в 1985 г. заведующий кафедрой КГМ профессор В. П. Аврамов был награжден орденом «Дружба народов», а ГО «Металхим» наградило ведущих преподавателей кафедры КГМ золотыми и серебрянными Почетными Знаками.

Негативные тенденции в экономике социалистических государств конца 80-х годов прошлого столетия, связанные с непродуманной программной конверсии оборонной промышленности этих стран, привели к переориентации предприятий на выпуск народнохозяйственной продукции и к разрыву связей между оборонными предприятиями стран Совета Экономической Взаимопомощи. Число командируемых в СССР на обучение студентов стало стремительно сокращаться.

В 1992 году защитили дипломные проекты последние студенты из Болгарии. Всего за 20 лет с 1972 по 1992 год для НРБ по специальности 15.06 было подготовлено около 200 специалистов.

Выпускники специальности 15.06 - гусеничные и колесные машины, командированные на учебу в ХПИ из НРБ, как правило, успешно работали на родине. Так, Людмил Георгиев стал генеральным директором МК «Девети май», С. Червенков - директором Машиностроительного техникума в г. Червен бряг, П. Парванов и В. Младенов - главными инженерами оборонных предприятий в г. Казанлык и г. Карлово. К сожалению, очень талантливые инженеры X. Николов, П. Хинов и Н. Калейчев вынуждены были уйти в частный бизнес. Но как бы ни сложилась дальнейшая судьба болгарских выпускников кафедры КГМ, все они сохранили самые добрые воспоминания об учебе в ХПИ и пребывании в Харькове, где они встретили самое дружеское расположение и оставили о себе добрую память. 